\title{
Physical-Chemical Analysis and Comparison with Standards of the Compost Produced in Sanandaj, Iran
}

\author{
Shahram Sadeghi1,2, Mahbobeh Dehvari ${ }^{3}$, Pegah Bahmani ${ }^{4}$, Pari Teymouri $^{4}$, \\ Ahmad Fattahi', Mojtaba Sadeghnia5, Reza Ali Fallahzadeh ${ }^{3 *}$ \\ ${ }^{1}$ Student Research Committee, Kurdistan University of Medical Sciences, Sanandaj, Iran \\ ${ }^{2}$ Department of Environmental Health Engineering, School of Public Health, Kurdistan University of Medical \\ Sciences, Sanandaj, Iran \\ ${ }^{3}$ Department of Environmental Health Engineering, School of Public Health, Shahid Sadoughi University of \\ Medical Sciences, Yazd, Iran \\ ${ }^{4}$ Department of Environmental Health Engineering and Environmental Health Research Center, Kurdistan \\ University of Medical Sciences, Sanandaj, Iran \\ ${ }^{5}$ Department of Occupational Health Engineering, School of Public Health, Shahid Sadoughi University of \\ Medical Sciences, Yazd, Iran \\ Email: ${ }^{\text {fallahzadeh4@yahoo.com }}$
}

Received 4 October 2015; accepted 20 October 2015; published 26 October 2015

Copyright (C) 2015 by authors and OALib.

This work is licensed under the Creative Commons Attribution International License (CC BY).

http://creativecommons.org/licenses/by/4.0/

(c) (i) Open Access

\begin{abstract}
Improper disposal of solid waste is one of the main causes of environmental pollution. Converting solid waste into compost and using it as an organic fertilizer in agriculture are an effective waste management method. Quality of such fertilizer may affect both human and environmental health. Therefore, in this study, compost from the compost plant of Sanandaj City was analyzed for its physical-chemical characteristics and the results were compared with the standards. In this descriptive-analytical study, compost samples were collected throughout a 3-month period in spring season at intervals of 15 days ( 2 samples in each sampling) for chemical analysis. In the present study, parameters such as $\mathbf{p H}$, organic matter, EC, carbon, nitrogen, phosphorus, sodium, potassium, arsenic, lead, cadmium, mercury and chromium were studied. According to the results, the mean $\mathbf{~ H , ~ E C , ~ o r g a n i c ~ m a t t e r , ~ c a r b o n , ~ n i t r o g e n , ~ p h o s p h o r u s , ~ s o d i u m ~ a n d ~ p o t a s s i u m ~ w e r e ~ 7 . 6 5 7 , ~}$ $8.883 \mathrm{ds} / \mathrm{m}, 37.793 \%, 26.46 \%, 2.50 \%, 0.424 \%, 0.685$ and $0.67 \%$, respectively. The average concentrations of heavy metals were $0.398,95,1.575,<0.5$ and $40.275 \mathrm{mg} / \mathrm{kg}$ for arsenic, lead, cadmium, mercury and chromium, respectively. Results from this study were compared with the standards set for compost. Organic matter content, sodium, arsenic, mercury and chromium were almost within the acceptable ranges. Lead and cadmium concentrations were lower than the standard. But, the values of $\mathrm{pH}$ and $\mathrm{EC}$, the percentages of carbon and nitrogen, and also the amounts of
\end{abstract}

\footnotetext{
${ }^{*}$ Corresponding author.
}

How to cite this paper: Sadeghi, S., Dehvari, M., Bahmani, P., Teymouri, P., Fattahi, A., Sadeghnia, M. and Fallahzadeh, R.A. (2015) Physical-Chemical Analysis and Comparison with Standards of the Compost Produced in Sanandaj, Iran. Open Access Library Journal, 2: e1855. http://dx.doi.org/10.4236/oalib.1101855 
phosphorus and potassium were in accordance with the standards. The results of this study show that the quality of the produced compost in the studied plant is almost acceptable.

\title{
Keywords
}

\author{
Compost, Physical-Chemical Analysis, Sanandaj
}

\author{
Subject Area: Environmental Sciences
}

\section{Introduction}

Solid wastes are environmental problems. Their inadequate management may endanger human and animal health and eventually cause economic, environmental and biological losses [1]. Therefore, the rules and standards in all aspects of solid waste management are important and require special attention. Waste reduction, reuse, recycling and converting organic wastes into valuable compounds are among the methods for reducing solid waste disposal problems [1] [2].

Composting is a process for converting solid waste into plant nutrients [1] [3] [4]. Different analyses on municipal waste in Iran indicate that there is a high percentage of perishable materials init (food wastes by more than $70 \%$ of the composition of such type of waste). Thus, composting seems to be an appropriate method for waste management [5]-[8].

In recent years, many countries worldwide use organic fertilizers such as compost, due to the economic aspect, environmental and health issues associated with organic matter and nutrients in it [9]-[11]. During composting, organic wastes, including household wastes (after removal of metal, glass and plastic), food waste, wastes from farms and forests, leaves and grasses from parks and gardens are biologically decomposed and under thermophilic conditions they are turned to stable matters such as humus [5] [12]-[14]. In other words, the compost is, in fact, decayed plant and animal remains, municipal solid waste or sewage sludges [6].

During the composting process, microorganisms break down the chemical bonds among the organic materials and convert them into carbon dioxide, water, heat (energy) and compost [2] [15]. Compost protects soil against wind, increases productivity, prevents soil erosion, reduces soil compaction, increases soil porosity and reduces plant toxicity and waste volume. Compost also supplies nutrients to the plant and improves the quantity and quality of the products regarding their smell and taste [2] [9] [16] [17].

The first compost plant in Iran dates back to 1959 in Isfahan. In later years, it was launched in other cities, as well [2]. Various parameters affect the efficiency of the compost production process and its quality. Oxygen, moisture and $\mathrm{C} / \mathrm{N}$ ratio are the main parameters. Organic matter, temperature, and waste acidity are the other effective parameters [5] [14] [18]. Sanandaj, the capital of Kurdistan Province, with a population of over 440 thousand people, produces 350 tons of waste daily, 200 tons of which find their way into the compost plant. The plant has an area of 5 hectares and is located at the southeast of Sanandaj and is surrounded by high hills. In this study, the quality of the final compost produced in Sanandaj compost plant was studied regarding its chemical properties.

There are different physical, chemical and biological standards set for compost from solid waste in production and consumption steps; ignoring them the social and environmental health will be threatened. The chemical properties of the studied compost were compared with the national, WHO, Gotas and Washington state department of ecology (WSDE) standards for compost (Table 1) [19].

\section{Materials and Methods}

In this descriptive-analytical study, the produced compost in the Sanandaj compost plant was studied regarding its chemical characteristics for three months. Sampling was at a 15 days interval and 2 samples were taken at each interval.

Parameters such as pH (measured using a pH- meter, model 3510 Jenway, England), EC (measured using an EC meter, model 4510 Jenway, England), organic matter and carbon (measured using cold titration and/or alkyl block method), nitrogen (measured using Kjedahl method), phosphorus (measured using a spectrophotometer, 
Table 1. The chemical properties of compost.

\begin{tabular}{|c|c|c|c|c|c|c|}
\hline \multirow{3}{*}{ Type of property } & \multicolumn{6}{|c|}{ Standard } \\
\hline & \multicolumn{2}{|c|}{$\begin{array}{l}\text { Institute of standards and } \\
\text { industrial research of Iran } \\
\text { (weight based on the dry matter) }\end{array}$} & \multirow[b]{2}{*}{$\begin{array}{l}\text { WHO standard } \\
\text { (gr/100gr) }\end{array}$} & \multirow[b]{2}{*}{$\begin{array}{l}\text { Gotas theory } \\
(\mathrm{gr} / 100 \mathrm{gr})\end{array}$} & \multicolumn{2}{|c|}{$\begin{array}{c}\text { Standard products } \\
\text { Washington ecology } \\
\text { department }\end{array}$} \\
\hline & $\begin{array}{l}\text { Acceptable range } \\
\text { for Category A }\end{array}$ & $\begin{array}{l}\text { Acceptable range } \\
\text { for Category B }\end{array}$ & & & Category A* & Category B* \\
\hline Organic materials & At least $35 \%$ & At least $25 \%$ & $10-20$ & $25-50$ & At least 50 & At least 40 \\
\hline Organic carbon & At least $25 \%$ & At least $15 \%$ & - & $50-80$ & - & - \\
\hline The amount of total nitrogen & $1.25 \%-1.66 \%$ & $1 \%-1.5 \%$ & $0.4 \%-3.5 \%$ & $0.4 \%-1.5 \%$ & At least $1 \%$ & At least $0.5 \%$ \\
\hline The ratio of carbon to nitrogen & $15-20$ & $10-15$ & - & - & Up to 15 & Up to 20 \\
\hline $\begin{array}{l}\text { The amount of phosphorus } \\
\text { in terms of } \mathrm{P}_{2} \mathrm{O}_{5}\end{array}$ & $1 \%-3.8 \%$ & $0.3 \%-3.8 \%$ & $0.3-3.5$ & $0.2-3.8$ & - & - \\
\hline $\begin{array}{l}\text { The amount of potassium } \\
\text { in terms of } \mathrm{K}_{2} \mathrm{O}\end{array}$ & $0.5 \%-1.8 \%$ & $0.5 \%-1.8 \%$ & $0.5-1.8$ & $0.1-2.8$ & - & - \\
\hline Sodium & - & - & - & - & - & - \\
\hline Arsenic (mg/kg) & - & - & - & - & - & - \\
\hline $\begin{array}{l}\mathrm{Lead} \\
(\mathrm{mg} / \mathrm{kg})\end{array}$ & - & - & $200-400$ & - & - & - \\
\hline Cadmium (mg/kg) & - & - & $15-40$ & - & - & - \\
\hline Mercury $(\mathrm{mg} / \mathrm{kg})$ & - & - & - & - & - & - \\
\hline Chromium (mg/kg) & - & - & - & - & - & - \\
\hline $\begin{array}{l}\text { Conductivity } \\
\text { (in } 10 \% \text { of dry matter) }\end{array}$ & Up to $8 \mathrm{ds} / \mathrm{m}$ & $\mathrm{Up}$ to $14 \mathrm{ds} / \mathrm{m}$ & - & - & $<2 \mathrm{mmohs} / \mathrm{cm}$ & $<3 \mathrm{mmohs} / \mathrm{cm}$ \\
\hline $\mathrm{pH}$ (in $10 \%$ of dry matter) & $6-8$ & $6-8$ & $6-8$ & $6-9$ & $5.5-6.5$ & $5-8$ \\
\hline
\end{tabular}

*Category A: for products that use in the human food chain and raw products. *Category B: Compost cannot be used for the food chain or for the raw products but can used of it for fruit orchards, forests and green space.

DR/2000 model Hach, American), sodium and potassium (both measured using a flame photometer, model Jenway, England) in the compost samples were studied. Concentrations of heavy metals including: arsenic, lead, cadmium, mercury and chromium (measured using and atomic absorption spectrophotometer, model) were also analyzed SPSS version 16 was used to statistical analysis of the results for each parameter. The final results were reported in percent as mean \pm standard deviation and, finally, the results were compared with standards.

\section{Results}

The results of physicochemical analysis of compost produced in Sanandaj are presented in Table 2.

\section{Discussion}

\subsection{Physicochemical Characteristic}

Since microorganisms can live at different $\mathrm{pH}$ values, its control leads to a better growth and activity of the bacteria. In this study, the average $\mathrm{pH}$ of 7.657 was obtained that was in the standard ranges except for the standard for Class A compost set by WSDE. EC represents the concentration of dissolved salts in the compost. Application of compost with high levels of EC may cause some problems including soil salinity and biological toxicity [16]. An average EC amount of $8.883 \mathrm{ds} / \mathrm{m}$ was found for the studied compost samples, which is in accordance with the standards. In a study by Fathi et al. (2014) on the compost produced from Zanjan municipal solid waste, they found that $\mathrm{pH}$ of produced compost was 5.45, which almost was in the standard range of $(5.5-8)$ [1]. Sefidkar et al. (2013) reported that $\mathrm{pH}$ and $\mathrm{EC}$ of their studied compost from Mashhad municipal solid waste are 
Table 2. The results of physicochemical analysis of compost produced in Sanandaj.

\begin{tabular}{|c|c|c|c|c|c|c|c|c|c|c|c|c|c|}
\hline Samples & $\underset{(\mathrm{mg} / \mathrm{kg})}{\mathrm{Cr}}$ & $\underset{(\mathrm{mg} / \mathrm{kg})}{\mathrm{Hg}}$ & $\underset{(\mathrm{mg} / \mathrm{kg})}{\mathrm{Cd}}$ & $\begin{array}{c}\mathrm{Pb} \\
(\mathrm{mg} / \mathrm{kg})\end{array}$ & $\begin{array}{c}\mathrm{As} \\
(\mathrm{mg} / \mathrm{kg})\end{array}$ & $\begin{array}{c}\mathrm{K} \\
(\%)\end{array}$ & $\begin{array}{l}\mathrm{Na} \\
(\%)\end{array}$ & $\begin{array}{c}\mathrm{P} \\
(\%)\end{array}$ & $\begin{array}{c}\mathrm{N} \\
(\%)\end{array}$ & $\begin{array}{c}\mathrm{C} \\
(\%)\end{array}$ & $\begin{array}{c}\mathrm{EC} \\
(\mathrm{ds} / \mathrm{m})\end{array}$ & $\mathrm{pH}$ & $\begin{array}{l}\mathrm{OM} \\
(\%)\end{array}$ \\
\hline 1 & 39.76 & $<0.5$ & 1.50 & 87.00 & 0.37 & 0.62 & 0.67 & 0.41 & 2.51 & 19.65 & 9.53 & 7.62 & 36.70 \\
\hline 2 & 37.92 & $<0.5$ & 1.53 & 92.43 & 0.35 & 0.63 & 0.72 & 0.39 & 2.29 & 18.77 & 8.65 & 7.53 & 38.26 \\
\hline 3 & 43.65 & $<0.5$ & 1.62 & 89.88 & 0.41 & 0.64 & 0.71 & 0.43 & 2.32 & 17.89 & 8.32 & 7.77 & 36.94 \\
\hline 4 & 41.00 & $<0.5$ & 1.57 & 94.65 & 0.44 & 0.63 & 0.72 & 0.43 & 2.41 & 25.21 & 7.90 & 8.13 & 37.30 \\
\hline 5 & 41.20 & $<0.5$ & 1.59 & 96.79 & 0.39 & 0.72 & 0.69 & 0.44 & 2.10 & 23.53 & 8.45 & 8.27 & 15.38 \\
\hline 6 & 38.45 & $<0.5$ & 1.58 & 103.1 & 0.38 & 0.69 & 0.64 & 0.38 & 2.86 & 28.78 & 8.20 & 7.50 & 39.35 \\
\hline 7 & 37.87 & $<0.5$ & 1.58 & 98.54 & 0.35 & 0.65 & 0.65 & 0.38 & 2.71 & 29.11 & 9.24 & 7.84 & 40.13 \\
\hline 8 & 40.00 & $<0.5$ & 1.59 & 95.00 & 0.41 & 0.67 & 0.73 & 0.41 & 2.54 & 26.58 & 9.70 & 7.28 & 38.11 \\
\hline 9 & 39.91 & $<0.5$ & 1.61 & 94.40 & 0.41 & 0.71 & 0.70 & 0.43 & 2.97 & 32.86 & 9.36 & 7.45 & 35.65 \\
\hline 10 & 41.17 & $<0.5$ & 1.63 & 97.32 & 0.43 & 0.70 & 0.66 & 0.41 & 2.60 & 36.33 & 8.76 & 8.54 & 38.50 \\
\hline 11 & 41.50 & $<0.5$ & 1.56 & 96.50 & 0.50 & 0.68 & 0.65 & 0.50 & 2.37 & 27.80 & 9.52 & 7.32 & 37.63 \\
\hline 12 & 40.87 & $<0.5$ & 1.54 & 94.37 & 0.34 & 0.71 & 0.68 & 0.48 & 2.43 & 30.98 & 8.97 & 7.63 & 36.80 \\
\hline Mean & 40.27 & $<0.5$ & 1.57 & 95.00 & 0.39 & 0.67 & 0.68 & 0.42 & 2.50 & 26.46 & 8.88 & 7.65 & 37.79 \\
\hline$\pm \mathrm{SD}$ & 1.667 & 0 & 0.038 & 4.120 & 0.045 & 0.36 & 0.031 & 0.037 & 0.247 & 5.737 & 0.59 & 0.30 & 1.230 \\
\hline
\end{tabular}

in an acceptable range [19]. In a study by Pan et al. (2013) $\mathrm{pH}$ values in the compost from wheat straw were 7, which were in the ranges offered by the standards [20].

\subsection{Organic Matters and Nutrients Compound}

Organic matters are among the parameters that affect the quality of the produced compost. The results of this study showed that $37.793 \%$ of the produced compost is organic matters. This value is in accordance with the standard values provided by the Institute of Standards and Industrial Research of Iran (ISIRI) and Gutas theory. But, it does not meet the standard values provided by WHO and the WSDE. The organic material in the compost produced in Zanjan City was 38/61\% [1], which is higher than the organic matters in the compost produced in Sanandaj and of coarse higher than the standards provided by Gutas and WHO.

Nutrients in compost are analyzed considering the raw materials used in the compost pile, and also the application of the final compost. Nutrients are necessary in the compost pile because decomposer microorganisms need them to grow, and also they are important regarding the fertilizer value of the final product. Among the nutrients, carbon, nitrogen, phosphorus, potassium, calcium, iron and manganese are the more important [12]. In the present study, the mean \pm SD of carbon, nitrogen, phosphorus and potassium in the compost was $26.46 \pm$ $5.737,2.50 \pm 0.247,0.424 \pm 0.037$ and $0.67 \pm 0.36$, respectively. WHO standards for nitrogen, phosphorus and potassium in compost are $0.4-3.5,0.3-3.5$ and $0.5-1.8(\mathrm{gr} / 100 \mathrm{gr})$, respectively. Therefore, results of this study meet WHO standards. Carbon to nitrogen $(\mathrm{C} / \mathrm{N})$ ratio is an important parameter in determining the quality of the produced compost. It can strongly affect the microbial population during the composting process. Raw materials must be combined in such a way that the ratio of carbon to nitrogen remains in the range of 25 to 30 and in desirable ratio of 30 to $1 . \mathrm{C} / \mathrm{N}$ ratio at the final product should be reduced to the range of 14 to 20 [5] [12] [16]. $\mathrm{C} / \mathrm{N}$ ratio for the present study was 8.45 , which is much lower than the standards. $\mathrm{C} / \mathrm{N}$ ratio in compost produced in Zanjan city was also lower than the standards (17.6) [1]. In such cases, materials such as wood chips, sawdust, bark, branches and leaves, food waste, straw, bran cereals, green waste, etc., should be added to the composting materials at the beginning of the process [21]. Pan et al. (2013) analyzed the physicochemical and biological characteristics of a compost from wheat straw. The results of this research indicate that a $\mathrm{C} / \mathrm{N}$ ratio of 17, which was in accordance with the standards [20]. Chemical analysis on the quality of the compost produced in Khomein and Tehran compost plants showed that the phosphorus concentration in these plants is 
lower than its standard set by Germany. The percentage of organic carbon in the compost of Tehran compost plat was higher than Khomein compost plant. But both were lower than the standards [22]. In another study on the compost produced in Tabriz, it was reported that compared to the standards, nitrogen, iron and $\mathrm{C} / \mathrm{N}$ ratio were higher but phosphorus was lower. Manganese and organic materials in this compost were desirable. In the compost produced in Isfahan, phosphorus and manganese levels met the standards, but the $\mathrm{C} / \mathrm{N}$ ratio, organic matter, nitrogen, potassium, calcium and iron, were higher, and magnesium and chlorine were lower than the standard limits [15]. According to the results of the present study, the concentration of sodium in the studied compost was equal to $0.685 \%$, which is almost acceptable.

\subsection{Heavy Metals}

Another important parameter in deciding on the compost quality is heavy metals (arsenic, lead, cadmium, mercury, chromium, etc.). Dyes, batteries, electronics, cosmetics and drug residues are the main sources of heavy metals in compost [5] [6] [9]. Due to the harmful effects of heavy metals on human and environmental, standards have been established for the concentration of these metals in the compost. The concentrations of lead and cadmium in the studied compost were 95 and $1.575 \mathrm{mg}$ per kg, respectively, which are lower than the recommended values. Compared with the standard values, concentrations of mercury, chromium and arsenic $(<0.5$, 40.275 and $0.398 \mathrm{mg} / \mathrm{kg}$ respectively) were almost acceptable. The maximum allowable concentrations of arsenic, cadmium, chromium, lead and mercury in Iran are 10,10,150, 200 and $5 \mathrm{mg} / \mathrm{kg}$ respectively [23]. According to the results of the present study, the concentrations of arsenic, cadmium and mercury are lower than there commended standard, and $\mathrm{Cr}$ and $\mathrm{Pb}$ concentrations are almost acceptable. Several studies have been conducted in different regions on compost quality. Physicochemical and biological characteristics of municipal solid waste compost during the composting process were studied by Shyamala et al. in 2012. They concluded that the $\mathrm{pH}, \mathrm{EC}$, organic carbon, organic matter, total phosphorus and potassium in the final stage (after 60 days) meet the standards, but the concentration of heavy metals were lower than the standards set by Ohaio EPA [24]. Heidarzadeh et al. (2008) studied the quality of the compost in Iran. The researchers reported that Tehran compost plant produces compost with higher amount of EC and concentration of heavy metals, such as copper and zinc, than the standard values, but, $\mathrm{C} / \mathrm{N}$ ratio lower than standards [25].

\section{Conclusion}

Due to its advantages, the use of compost in agriculture and the environment is important. To ensure the quality and safety of compost, it is necessary to analyze and monitor the physical, chemical and microbial parameters during the composting process. In this study, the chemical characteristics of the compost produced by the Sanandaj compost plant were investigated. Results indicated a good quality of the studied compost. Only a limited number of parameters (As, $\mathrm{Cd}$ and $\mathrm{Hg}$ ) did not meet the standards.

\section{Acknowledgements}

The authors appreciate the support of this project by the Student Research Committee, Deputy of Research and Technology, Kurdistan University of Medical Sciences

\section{References}

[1] Fathi, H., Zangane, A.H., Fathi, H. and Moradi, H. (2014) Municipal Solid Waste Characterization and It Is Assessment for Potential Compost Production: A Case Study in Zanjan City, Iran. American Journal of Agriculture and Forestry, 2, 39-44. http://dx.doi.org/10.11648/j.ajaf.20140202.14

[2] Ziaee, S., Omrani, G., Agha, M.M.A. and Mansouri, N. (2012) Qualitative and Quantitative Examination of Household Hazardous Waste in Tehran. Advances in Environmental Biology, 6, 676-683.

[3] Jha, A.K., Li, J., Nies, L. and Zhang, L. (2013) Research Advances in Dry Anaerobic Digestion Process of Solid Organic Wastes. African Journal of Biotechnology, 10, 14242-14253.

[4] Mbuligwe, S. and Kassenga, G. (2005) Feasibility and Strategies for Anaerobic Digestion of Solid Waste for Energy Production in Dar-es-Salaam City Tanzania. Resources Conservation \& Recycling, 42, 183-203. http://dx.doi.org/10.1016/i.resconrec.2004.02.010

[5] Amouei, A., Asgharnia, H.A. and Khodadi, A. (2009) Study of Compost Quality from Rural Solid Wastes (Babol, Iran). 
Journal of Mazandaran University of Medical Sciences, 20, 55-61. (In Persian)

[6] (2005) Interpreting Waste \& Compost Tests. Journal of the Woods End Research Laboratory, 2, 1-6.

[7] Sangsefidi, Z., Ahmadi, A. and Qurchian, H. (2005) Environmental Risks of Using Compost from Mixed Municipal Waste. 8th National Conference on Environmental Health, Tehran, 15-17 November 2005, 308-313. (In Persian)

[8] Abdoli, M.A. (2005) Municipal Solid Wastes Recovery. Tehran University Publishing, Tehran, 12-14.

[9] Rastgar, A., Joneidi, Jafari, A., Farzadkia, M., Rezaei Kalantary, R., Allah-Abadi, A. and Gholizadeh, A. (2012) The Effect of Solid Waste Compost on Leaching and Adsorption of Heavy Metals from Silt-Loamy Soils. Journal of Sabzevar University of Medical Science, 19, 277-286. (In Persian)

[10] Ghiamati, G., Astaraei, A. and Zamani, G. (2009) Effect of Urban Solid Waste Compost and Sulfur on Sugar and Beet Yield and Soil Chemical of Properties. Iranian Journal of Field Crops Research, 7, 155-164.

[11] Sharholy, M. (2008) Municipal Solid Waste Management in Indian Cities-A Review. Waste Management, 28, 459467. http://dx.doi.org/10.1016/j.wasman.2007.02.008

[12] Abbasi, F.M., Ahmad, H., Perveen, F., Sajid, M. and Brar, D.S. (2010) Assessment of Genomic Relationship between Oryza sativa and Oryza australiensis. African Journal of Biotechnology, 9, 1312-1316.

[13] Haug, R.T. and Haug, H.T. (1993) Practical Handbook of Compost Engineering. Lewis Publishers, Boca Raton.

[14] Yaghmaeian, K. (1980) Study of Compost Production from Solid Waste in Semnan. Master's Thesis, Health School, Tehran University of Medical Sciences, Tehran, 112-115.

[15] Zazooli, M., Bagheri, M., Ghahremani, E. and Ghorbanian, M. (2009) Principles of Compost Technology. Khaniran Pub, Tehran, 245-271. (In Persian)

[16] Malakootian, M., Yaghmaeian, K. and Mobini, M. (2014) Feasibility of the Compost Production Using Pistachio Hull and Mixed of Pistachio Hull and Broiler Litter. TB, 12, 24-35.

[17] BioAbfV (1998) German Bioabfallverordnung, Bundesgesetzblatt (Utilization of Bio Wastes on Land Used for Agricultural, Silvicultural and Horticultural Purposes).

[18] Tchobanoglous, G. and Theisen, H. (2003) Integrated Solid Wastes Management Engineering Principles and Management Issues. 3rd Edition, McGraw Hill, New York, 39-67.

[19] Sefidkar, E., Kazemi, M.A., Mohebbrad, B. and Sadeghi, A. (2013) Chemical Analysis of the Compost Produced in Mashhad City and Comparison with Standards. Journal of North Khorasan University of Medical Sciences, 5, 775-782.

[20] Ieshita Pan, S.K. (2013) Microbial and Physic-Chemical Analysis of Composting Process of Wheat Straw. Indian Journal of Biotechnology, 12, 120-128.

[21] Rynk, R. (1992) On Farm Composting Hand Book, Northeast Regional Agricultural Engineering Service. Riley-Robb Hall, Ithaca, 255-7654.

[22] Farzadkia, M., Salehi, S., Ameri, A., JoneidyJafari, A. and Nabizadeh, R. (2009) Study on the Quality and Comparing of the Compost Produced by Khomain and Tehran Compost Factories. IJHE, 2, 160-169. (In Persian)

[23] Silespour, M. (2011) Municipal Composting and Its Heavy Metals Standards. Agriculture and Sustainable Development, 34, 18-23.

[24] Shyamala, D.C. and Belagali, S.L. (2012) Studies on Variations in Physico-Chemical and Biological Characteristics at Different Maturity Stages of Municipal Solid Waste Compost. International Journal of Environmental Sciences, 2, 1984-1997.

[25] Heidarzade, N. and Abdoli, M. (2008) Quality Assessment of Compost in Iran and the Need for Standards and Quality Assurance. Journal of Environmental Studies, 34, 29-40. (In Persian) 